\title{
GUIDELINES FOR THE GASTRONOMY OF DOBROGEA, FOUNDATION FOR THE DEVELOPMENT OF THE LOCAL GASTRONOMIC TOURISM
}

\author{
Laetitia Casangiu Siea* \\ Bucharest University of Economic Studies, Bucharest, Romania, laetitia.casangiu@gmail.com
}

\begin{abstract}
In the present study we analyse aspects related to the culinary side of the region of Dobrogea (Romania). The main research methods for the present article were the comparative study of specialized literature, with coverage of the main publications dedicated to the chosen topic, and the survey done through a questionnaire, launched with the purpose of checking the level of knowledge of the gastronomy of Dobrogea among the consumers and to identify its characteristic elements in order to consider it as vector for the local gastronomic tourism. The results of our research have highlighted the fact that customers give a high importance to the culinary aspect when choosing a holiday destination, and that the local Dobrogean dishes, wines, desserts and the quality products which have received recognition at a European level are not sufficiently known by the general public. This fact is due, on one side, to the insufficient information given about the geographical origin of the products during the marketing and sale phase and, on the other side, to a general lack in promotion for Dobrogean products, especially in other regions of Romania and abroad.
\end{abstract}

Keywords:

Culinary tourism, Dobrogea, food, gastronomic tourism, local food

JEL Classification: A13, Z32

DOI: $10.24818 / \mathrm{CTS} / 3 / 2021 / 2.05$

\section{Introduction}

Stakeholders and researchers in tourism dedicate significant attention to the analysis of the phenomenon of gastronomic tourism. They consider that the culinary aspect plays an increasingly important role in choosing a holiday destination and, therefore, it can become an important tool of promoting a geographic location, region, or area.

According to the World Food Travel (2021), "Food tourism is the act of traveling for a taste of place in order to get a sense of place", this definition including both food and drinks. In the specialized literature we can find more terms that define the same type of activity: 'food and wine tourism', 'tasting tourism', 'gourmet tourism', 'culinary tourism', 'food tourism', 'food travel', or 'gastronomic tourism'. World Food Travel Association has created a terminology glossary that classifies the various contexts in which the terms 'culinary tourism', 'food tourism', and 'gastronomic tourism' are used, otherwise equivalents, only the context in which are used and the mother tongue of the users being different. As for 'gourmet tourism', it "is a form of tourism that has as its main and exclusive motivation the great interest in the field of food; for example, making a first-time trip to a particular restaurant, a specific market or a cellar. All or almost all activities during the journey are related to food / good eating" (Nistoreanu, Nicodim and Diaconescu, 2018, 713).

Starting from the premise that Dobrogea is a region rich in food products, coming from agricultural and fishing activities, with a varied cuisine, it can be assumed that its gastronomy could be showcased more strongly and transformed into a powerful local brand. A direct consequence of this approach would be

\footnotetext{
* contact author
} 
the development of the local gastronomic tourism, which could contribute to the expansion of tourist flows beyond the peak seasons, both in terms of coastal and Danube Delta tourism.

In this study we aim to verify the level of knowledge of the main characteristic elements linked to the reputation of the gastronomy of Dobrogea among customers, whether they have links with this region or not. The initial hypothesis was that there is not yet a thorough knowledge of the culinary aspects defining this area and that their promotion is not enough.

\section{Literature review}

The first studies at an international level that dealt with the analysis of the dynamics created by the gastronomic tourism, nowadays an increasing phenomenon, date back to the beginning of the 80's when François Bélisle, in an article focused on the Caribbean region, on the one hand underlines the connection between the touristic phenomenon and the local food production, and on the other hand warns about the diminishing net economic impact generated by touristic activities because of food import from abroad (Bélisle, 1983).

An important definition is the one given by Long: "Culinary tourism is about food as a subject and medium, destination and vehicle, for tourism. It is about individuals exploring foods new to them as well as using food to explore new cultures and ways of being. It is about groups using food to sell their histories and to construct marketable and publicly attractive identities, and it is about individuals satisfying curiosity." (Long, 2004, 20).

The food aspect can have a predominant role in choosing a holiday destination: "gastronomy and culinary tourism can be described as tourism where any opportunity for memorable food and drink experiences contributes significantly to travel motivation and behaviour" (Ottenbacher and Harrington, $2010,14)$. In another study, gastronomic tourism is analysed in close connection with the local foodstuff: "Culinary tourism is any tourism experience in which one learns about, appreciates or consumes branded local culinary resources. In other words, culinary tourism is an international and reflective encounter with any culture including one's own through culinary resources" (Xiao and Smith, 2008, 289). The importance of the local foodstuffs has been underlined by other authors too, these representing "an essential part of a holiday experience [...] Culinaria and gastronomy play a pivotal role in the marketing of some tourist destinations" (Kivela and Crotts, 2006, 356).

Regarding the activities carried out, C. Michael Hall and Liz Sharples consider that gastronomic tourism consists in the "visitation to primary and secondary food producers, food festivals, restaurants and specific locations for which food tasting and/or experiencing the attributes of specialist food production region are the primary motivating factor for travel". (Hall and Sharples, 2003, 10). For Richards (2002), gastronomic tourism represents ,travels from which tourists can learn the producing process of foods, cooking methods, ingredients used to the culinary culture of the region". According to another definition, gastronomic tourism "is a journey, in regions rich in gastronomic resources, which generate recreational experiences or have entertainment purposes, which include: visits to primary or secondary producers or gastronomic products, gastronomical festivals, fairs, events, cooking demonstrations, food tastings or any activity related to food" (Lee, Packer and Scott, 2015). Other researchers think that "The notion of gastronomic tourism is applicable to tourist and visitors who plan the trip entirely or partially in order to taste the local product or to take part in activities that are related to gastronomy" (Gheorghe, Tudorache and Nistoreanu, 2014, 12). The purchase and consumption of traditional foodstuffs or observing the production process of the food (from agriculture to cooking schools) represents the main motivation or activity during the trips included in this type of tourism (Ignatov and Smith, 2006).

Many European and worldwide cities (Lyon, Parma, Hong Kong) are trying to develop a local brand starting from the culinary aspect. Unfortunately, though, not all the regions are successful in this endeavour to offer their inhabitants and visitors authentic culinary experiences. In a study published in 2000, Hjalager and Corigliano made a comparative research between Denmark and Italy with the goal to underline the fact that, in order to turn a region into a gastronomic tourist destination, the actions taken in the field of tourism are not enough if the national economic, agricultural and food policies do not converge uniformly towards the same goal. They underline that in Denmark food production is heavily industrialized, many times the image of quality product being compromised, as opposed to Italy where agricultural and food policies focus particularly on the freshness of the product, food control and 
tradition. They also think that, to turn a region into a gastronomic tourist destination, the essential condition to being successful is for its cuisine to be the result of historic transformations/processes and of the natural and cultural resources. (Hjalager and Corigliano, 2000).

This aspect is not always confirmed in reality. According to the examples mentioned in an article that emphasizes the reasons why the Israelian region Negev is not a gastronomic attraction (Hillel, Belhassen and Shani, 2013, 200), the cuisines can also emerge far away from their originating environment and from the local constraints of natural and cultural resources (Wilk, 2002). They also emphasize that the cuisines, for instance the new Asian cuisine, can be invented by the marketing professionals rather than being the result of some long on-going historic processes.

Local or regional resources can be divided into two big categories (Gumuchian and Pecqueur, 2007): generic resources, that can be reproduced easily in another place (for example, the construction of clusters and infrastructures), and resources specific to a region, that are linked to its identity and cannot be copied and implemented in another space. An essential role in the identification and use of territorial resources is played by the human factor as the definition of territorial resource itself implies groups of people anchored in physical spaces (Gumuchian and Pecqueur, 2007, 234).

"Gastronomy is a distinctive and strategic element in defining the image and brand of tourist destinations", is the conclusion of a survey carried out on the occasion of the publishing of "Global Report on Food Tourism" (UNWTO, 2012). On the same occasion, however, only 67,6\% of the respondents thought that their country had at that time a structured brand regarding the gastronomy, the rest thinking that there was a lot to be done about the strategic thinking in terms of gastronomic tourism.

For a region to be defined as cluster of gastronomic tourism, it requires the involvement of many more actors that World Food Travel Association (https://worldfoodtravel.org/) divides in three categories which are illustrated in the image below: Travel \& Hospitality, Food \& Beverage and a third category that includes the Government, the Educational Establishments, Media, etc.:

\section{FOOD TOURISM INDUSTRY CLUSTER}

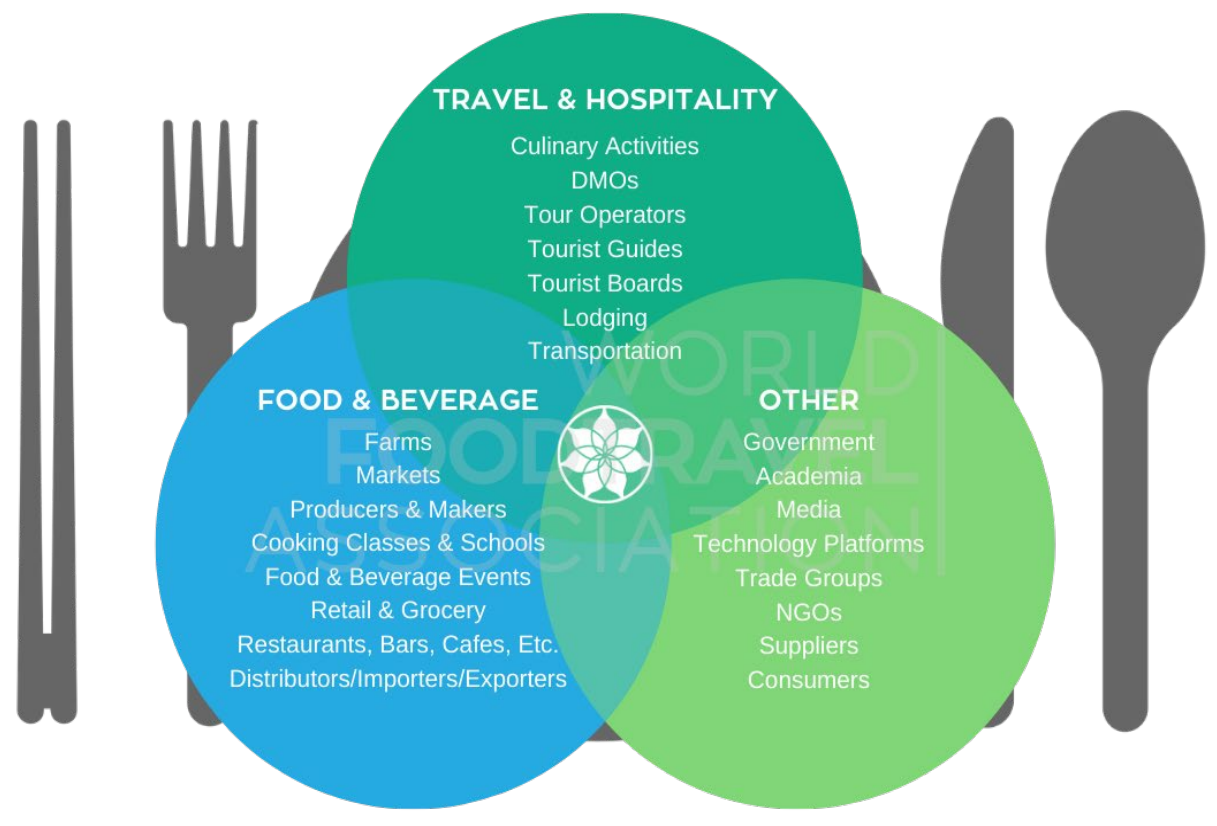

Fig. no. 1: Food Tourism Industry Cluster

Source: https://worldfoodtravel.org/what-is-food-tourism/ 
For a region or locality to become a landmark on the map of gastronomic tourism, the participation and interaction of more subjects is therefore necessary.

The gastronomy of a territory is the result of the combination of its natural resources and the skills of its inhabitants, who, by combining local raw materials, produce dishes that are part of the culinary tradition of the place they belong to.

\section{Methodology}

The main research methods for the present article were the comparative study of specialized literature, with coverage of the main publications dedicated to the chosen topic, and the survey done through a questionnaire, launched with the purpose of checking the level of knowledge of the gastronomy of Dobrogea among the consumers and to identify its characteristic elements in order to consider it as vector for the local gastronomic tourism. The questionnaire, carried out in two stages, in SeptemberOctober 2020 and March 2021, was filled in by 265 people. A part of the questions has already been processed and developed, being the object of research for another article (Casangiu Siea L, 2021).

\section{Results}

We will focus the present study on Dobrogea, a historical region of Romania located in the south-eastern part of the country, made up of Constanța and Tulcea, counties that in 2011 had a total population of 897.165 inhabitants (Tulcea 213.083 and Constanța 684.083), comprised of 19 different ethnicities.

In order to outline the characteristics of this region's food system, one must take into account ethnographic, anthropological, sociological and ethnological factors. As Ofelia Văduva (Văduva, 2010) points out, food is, in this complex multi-ethnic context, an element that both 'unites and divides'. Therefore, even if each ethnic group has its own values, traditions and customs, by living together in the same space for hundreds of years, they have borrowed defining aspects from the culture of other communities, because, as Massimo Montanari said,"Food models and practices are meeting points among diverse cultures, the fruit of man's travel, of commercial markets, techniques, and tastes from one part of the world to another."(Montanari, 2004, 138).

In the online distribution of the questionnaire created with "Google Forms", we took into account for the respondents to be both locals from Dobrogea and from other regions of the country.

As personal data, the respondents belong to the following age groups: $45-55$ years old - 41\%, 35-45 years old $-27,8 \%, 25-35$ years old $-12,4 \%, 55-65$ years old $-11,7 \%, 65-75$ years old $-4,5 \%, 18-25$ years old $-2,6 \%, 75-85$ years old $-0,4 \%$.

Of these, $72,8 \%$ are females, and $27,2 \%$ are males, and as level of education $43,4 \%$ graduated university studies, $36,7 \%$ post-university studies, $16,9 \%$ high school level, $1,9 \%$ secondary education.

Regarding geographical affinity, $49 \%$ have never lived in Dobrogea, so they do not have a knowledge of this region consolidated over time, while $51 \%$ declared that they live or lived here, so they know from direct experience the specific aspects of this region, including those related to gastronomy.

One of the questions of the questionnaire concerned the identification of Dobrogea with a certain identity element. The method of data analysis was that of examining the distribution of the frequencies (more key words could be indicated in every answer), and the results after the processing of the answers were: $36,6 \%$ identified Dobrogea with the Black Sea and the seaside, $11 \%$ mentioned Danube Delta, 13\% indicated multiculturalism and only $7 \%$ made references to the culinary aspects. Other answers regarded the link with the Danube (3,7\%), with the mountains (3,7\%).

"By correlating these data, it results that food, and the gastronomy of Dobrogea in general, do not yet represent in the collective mind a distinctive element as powerful as the others (sea, seaside, delta, multiculturalism)." (Casangiu Siea L, 2021).

From a geographical point of view, Dobrogea is divided into two macro-areas, that of the Black Sea in which seaside, spa, and recreational and leisure tourism developed, and the Danube Delta, in which sports and recreational and leisure tourism developed. A common element that connects the two macroareas is that related to the gastronomic aspect. 
Depending on the main raw materials used, the cuisine of Dobrogea can therefore be divided into two macro-areas: an area occupied by fish and its derivatives and one of meat, dairy and vegetable dishes (Știucă, 2013), to which we add fruit. However, if we talk about the influence of the locals on the cuisine of Dobrogea, we can say that to the main background of the Romanian majority's cuisine, which throughout history has been improved and transformed by contamination with the cuisines of other cultures and civilizations with which they came into contact (Turkish, Russian, Bulgarian, etc.), we can add the cuisines of the minority communities living on the territory of Dobrogea.

For the next two questions a Likert scale was Made, with 5 intensities of value, from 1 (none) to 5 (very much), in order to probe the importance of the gastronomic aspect in choosing a holiday.

Thus, for the question „How much does the gastronomic aspect matter to you when choosing a holiday?” (from 1 - none to 5 - very much), the answers were as follows: 4,9\% none, 5,7\% a little, $27,9 \%$ moderate, $35,1 \%$ a lot, $26,4 \%$ very much. So, for $61,5 \%$ of the respondents the gastronomic aspect has a big proportion in choosing a holiday place. These results show an improvement of the situation emphasized after a quantitative research carried out on the occasion of the Romanian Tourism Fair on February 2224,2018 , that had as main objective the identification of the position of gastronomy in the preferences of the Romanian travelers: „Although local cuisine has been recognized as an important criterion for distinguishing tourist destinations, contributing to the creation of a memorable travel experience, less than $30 \%$ of respondents indicate it as a criterion for choosing a holiday destination, which requires the intensification of the concerns of all "local actors" in the development and promotion of culinary tourism products, thus enhancing the attractiveness of tourist destinations and, on this basis, shaping gastronomy as an element of formation and orientation of tourist flows" (Nistoreanu et al, 2018, 682).

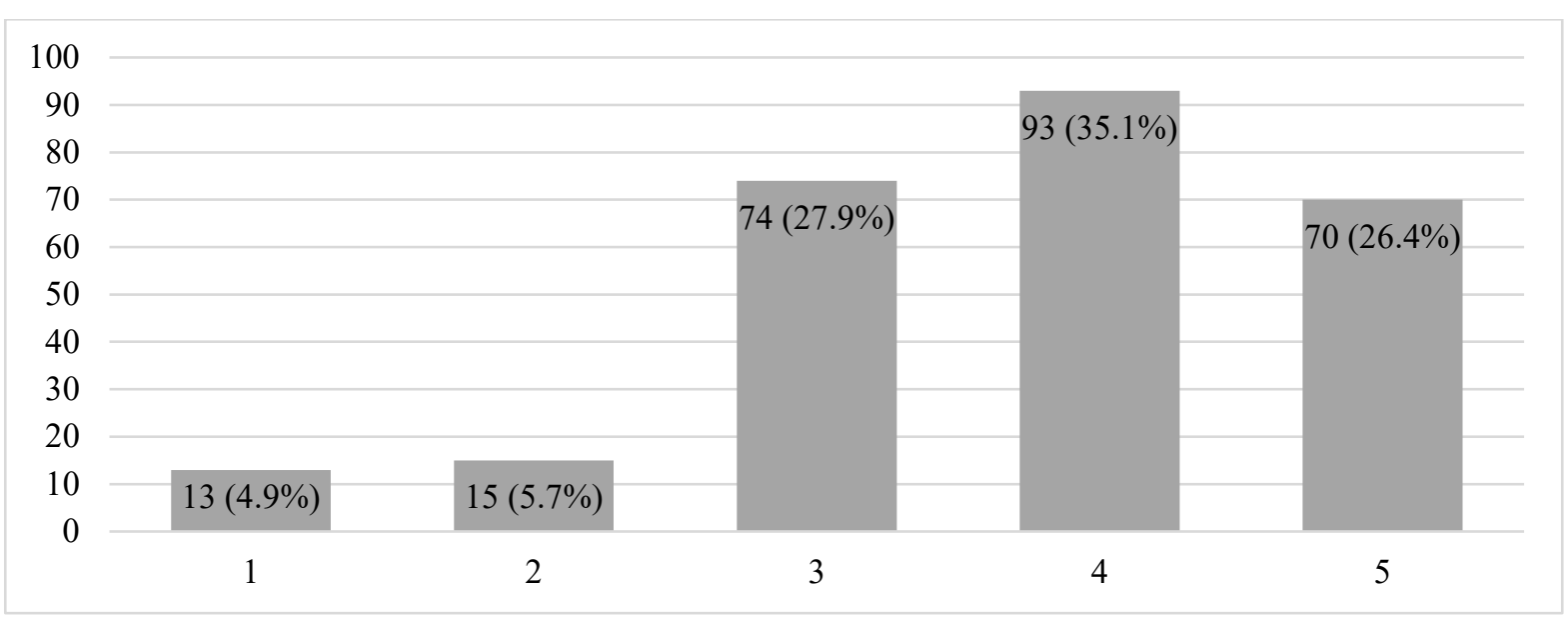

Fig. no. 2: processing of the answers to the question „How much does the gastronomic aspect matter to you when choosing a holiday?" (from 1 - none to 5 - very much)

Source: Own research

The same question, reported to Dobrogea, had the following answers: 7,9\% none, 7,5\% a little, 27,4\% moderate, $29,3 \%$ a lot, $27,8 \%$ very much. Even if the proportion of $57,1 \%$ of those for which the culinary aspect counts a lot and very much is not that high as in the case of the previous answer $(61,5 \%)$, the culinary aspect is very important in the overall decisions that determine the choice of a type of holiday and the agents in the field should take into account this market section and come up with adequate proposals. 


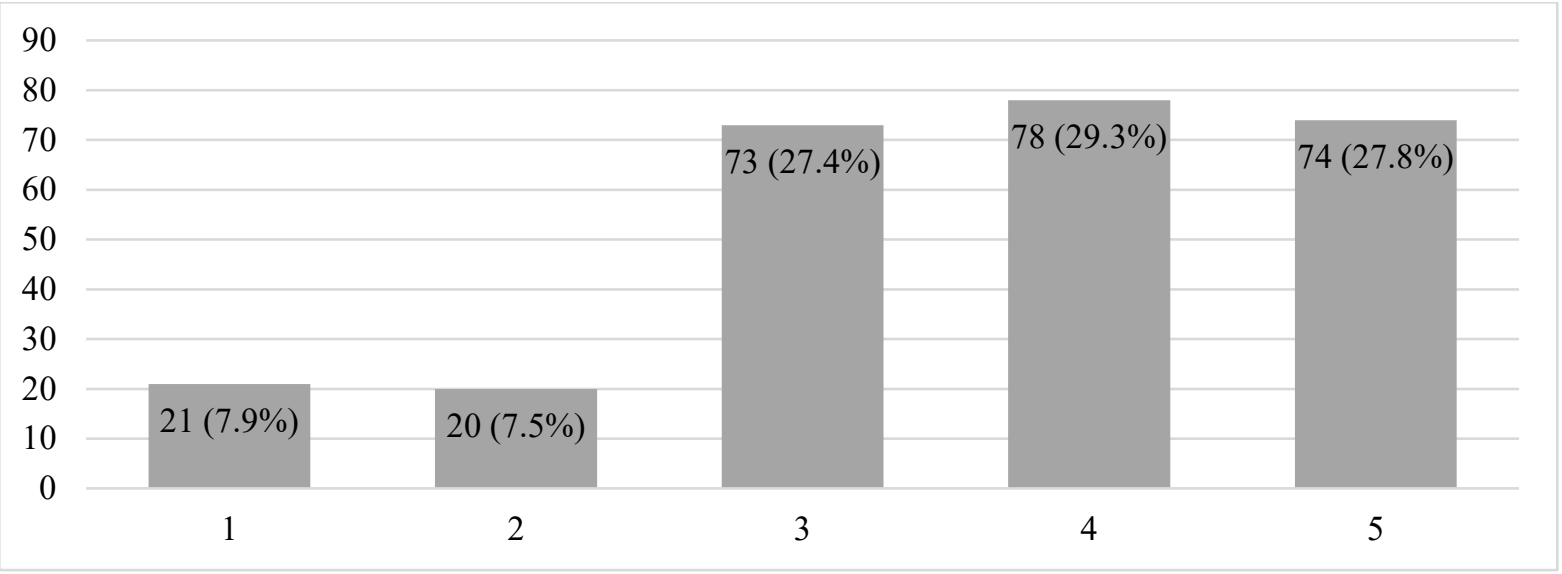

Fig. no. 3: processing of answers for the question "How much does the gastronomic aspect count for you when choosing a holiday in Dobrogea?" (from 1- none, to 5- very much)

Source: Own research

Other questions were open-ended ones and regarded the level of knowledge of the cuisine and wines from Dobrogea. The analysis method of the data was that of identifying the notorious elements.

As Stelian Nistor emphasizes, "the cuisine of Dobrogea stands on two feet: on sheep and on fish. The sheep is from the land, the fish is either from the sweet water of the Delta or from the salty water of the Black Sea. Swirled by various influences, Tatars, Greek, Turkish, Lipovans and who knows how many may have been, these basic types of meat led to the appearance of a variety of food specialities that can bring down any tourist." (Nistor, 2004, pp.86)

Unfortunately, $19 \%$ of the respondents provided a negative response as they did not know any gastronomic specialities or wines from Dobrogea, and 23\% did not know to give example of any dessert from Dobrogea.

For the people who do not know Dobrogea well enough, the culinary aspect is not sufficiently known yet, its better promotion being necessary locally, nationally, and internationally, starting precisely from the elements that are considered representative and emphasized in this research. Also, the local tourism could be varied and intensified by integrating guidelines from the culinary field.

The next set of questions had as objective the verification of the existence of an offer of local Dobrogea specialities in restaurants. To the first closed-ended question - "Have you ever been in a restaurant with specialities from Dobrogea?", 50,9\% responded affirmatively and 49,1\% negatively. To the question "Did you find in the menus of the restaurants from Dobrogea culinary specialities typically from Dobrogea?", the answers were 48,2\% "yes", 12,3\% "no" and 39,5\% "maybe yes, but we did not identify them as such", the last one being also a negative type of answer.

The third question from this set - "But did you find culinary specialities from Dobrogea in the menus of restaurants from other areas of Romania?" - had the following answers: $27,8 \%$ yes, $28,1 \%$ no, $44,1 \%$ "maybe yes, but we did not identify them as such".

From the processing of the received answers, the conclusion is that, in the consumers' perception, in Dobrogea there are restaurants that emphasize certain dishes from the menu as being specialities from Dobrogea, while in other areas of the country the possible specialities from Dobrogea offered to the consumers cannot be identified as such. The proposal is that of emphasizing the dishes from Dobrogea by mentioning the origin of the products in the menu, and the development of a local consciousness that also includes the culinary aspects.

The next two questions regarded the extent of familiarization of the respondents with quality Romanian foodstuffs, and especially with those from Dobrogea, registered at European level as PDO, PGI and TSG. These are open-ended questions whose purpose was to check the degree of reputation of certain products. 
Regarding the mentioning of Romanian foodstuffs protected at European level, 54\% of the respondents did not know to indicate any, 29\% mentioned Salam de Sibiu, 21\% Cârnați de Pleșcoi, 19\% Magiun de Topoloveni, 2,6\% Telemeana de Sibiu, 2,6\% Scrumbia afumată de Dunăre, 1,1\% Novacul afumat de Țara Bârsei.

These results are similar with those of a previous study published in 2019 in which: "The results revealed the majority of the respondents didn't know ( $80.3 \%$ for PGI logo and $78.6 \%$ for PDO logo) the significance of PGI and PDO logos. Among GI Romanian products, the highest levels of awareness and consumption are for PGI Salam de Sibiu, followed by PGI Magiun de Topoloveni. Carnati de Plescoi and Telemea de Sibiu are well known among respondent although they are not products with GI (some, at this moment, are submitted for registration)" (Nistoreanu et al, 2019, 537).

As for indicating foodstuffs from Dobrogea protected at an European level, 84,5\% of the respondents did not indicate anything, 4,5\% Scrumbia afumată de Dunăre, 1,13\% Plăcinta dobrogeană, 3,3\% salata de icre, and $4,5 \%$ of the answers were not relevant.

We mention that in July 2021, Romania had 71 products registered in the registry of established recipes at European level (GIview - https://www.tmdn.org/giview/gi/search): 53 wines, 9 spirit drinks, 9 foodstuff. Another foodstuff is undergoing verification.

Among these, the following can be attributed to Dobrogea:

- 7 wine denominations: Adamclisi (PDO), Babadag (PDO), Colinele Dobrogei (PGI), Murfatlar (wine, PDO), Murfatlar (liqueur wine, PDO); Sarica Niculițel (PDO); Terasele Dunării (PGI);

- a spirit alcoholic drink: Vinars Murfatlar (PGI);

- 2 foodstuffs: Scrumbie de Dunăre afumată (PGI); Salată cu icre de știucă de Tulcea (PGI). Another foodstuff speciality is in the process of registration: Plăcintă dobrogeană (PGI).

A question regarded the perception towards promoting the products from Dobrogea at fairs and exhibitions:

"Did you find stands/stalls/outlets with foodstuffs from Dobrogea at the local fairs, in our country or from abroad? In case of an affirmative answer, give more details."

A great part of the respondents, $75 \%$, provided a negative response. Other responses (20) described local experiences, especially those from the Fair organized at the Exhibition Centre from Constanța or from Harvest Day in Cumpăna. A few respondents mentioned the tourism fair and just one answer provided a description of an international experience: that is taking part "in 2017 in an international festival in Warsow, Poland, where there was a Romanian stand. Romanians from Dobrogea also took part, dressed in traditional costumes". As products, they mentioned dairy, bakery, but also Turkish and Tatar sweets.

This type of events contributes to the development of a culinary identity of the region and occasions to promote the local producers: "Festivals and local fairs are the focus of political and media attention, which also contribute to territorial cohesion. Since antiquity, festivals, fairs, and local markets have served as meeting places for eating and drinking, where people have also met to do business and trade, establish matrimonial alliances, and exchange information. This networking process is magnified today by information and communication technologies and social media" (Bellini, Clergeau and Etcheverria, 2020, 107-108).

\section{Conclusions}

From the data mentioned above, it results that the gastronomic aspect is essential in choosing holiday destinations, and recent research shows that this trend is constantly increasing. Unfortunately, the cuisine from Dobrogea is yet insufficiently known and a better promotion is needed. Turning Dobrogea into a destination of gastronomic tourism, in which „,food itself can be a destination for tourism, not only a vehicle" (Long, 2004), would bring many advantages to the entire territory, among which the support of the local producers from the entire agri-food chain (,from farm to fork”), job creation for a longer period of the year, not just during the summer season, as well as the diversity of the touristic activities.

Therefore, the main proposals go towards identifying an inventory of local products from Dobrogea, representative for the culture, history and identity of this region, with the description of their origin and of their ingredients in the menus of the restaurants in Dobrogea, as well as in other places in the country. 
In addition, another necessity is that of building a storytelling of the local products and culinary specialties, with emphasis on both the importance of the natural factors and on the craftsmanship of the people from these places, and particularly on the multicultural aspect of the region that also reflects itself on its gastronomic tradition.

Another proposal regards a better information of the consumers about the quality and originality of the products registered and protected at a European level (PDO, PGI, TSG).

Lastly, a strategic plan of local and national public authorities should be developed with the consultation of private stakeholders, for promoting the gastronomy of Dobrogea. This should include the participation in events and activities carried out locally, nationally, and internationally, such as tastings and teaching activities, participation in culinary fairs, exhibitions, and festivals.

\section{References}

Belisle F.J., 1983, Tourism and food production in the Caribbean, Annals of Tourism Research, 10 (4): $497-513$

Bellini N., Clergeau C., Etcheverria O., 2020, 1st Edition, Gastronomy and Local Development. The quality of products, places and experiences, Routledge Advances in Regional Economics, Science and Policy

Casangiu Siea L., 2021, Gastronomic Dobrogea, Between Identity and Identities. In: R. Pamfilie, V. Dinu, L

Tăchiciu, D. Pleșea, C. Vasiliu eds. 2021. 7th BASIQ International Conference on New Trends in Sustainable Business and Consumption. Foggia, Italy, 3-5 June 2021. Bucharest: ASE

Gumuchian H. and Pecqueur B., 2007, La ressource territoriale, Economica, Paris

Gheorghe G., Tudorache P. and Nistoreanu P., 2014, Gastronomic tourism, a new trend for contemporary tourism, in Cactus Tourism Journal Vol.9, Issue 1, Pages 12-21, ISSN 2247-3297

Harrington R.J. and Ottenbacher M. C. (2010) Culinary Tourism-A Case Study of the Gastronomic Capital. Journal Of Culinary Science \& Technology, 8(1), 14-32.

Hillel D., Belhassen Y. and Shani A., 2013, What makes a gastronomic destination attractive? Evidence from the Israeli Negev, in Tourism Management, 36, 200-209

Hjalager A. M. and Corigliano M. A., Food for tourists - determinants of an image, 2000, International Journal of Tourism Research, Vol.2, Issue 4

Kivela J. and Crotts J., 2006, Tourism and Gastronomy: gastronomy's influence on how tourists experience a destination, Journal of Hospitality \& Tourism Research, Vol. 30, no. 3, 354-37

Lee K-H., Packer J. and Scott N., 2015, Travel lifestyle preferences and destination activity choices of Slow Food members and non-members, Tourism Management, Volume 46, February 2015, Pages 1-10

Long L., 2004, Culinary tourism: A folkloristic perspective on eating and otherness. Culinary Tourism. 55. 20-50

Meyronin B., 2015, Marketing territorial - Enjeux et pratiques, Ed.Vuibert, France

Montanari M., 2004, Food is culture, Columbia University Press, New York

Nistor S., 2004, Ghidul gastronomic al României, House of Guides, Bucharest

Nistoreanu B. G., Nicodim L. and Diaconescu D. M., 2018, Gastronomic Tourism- stages and evolution, Proceedings of the International Conference on Business Excellence, vol. 12, no. 1, pp. 711-717.

Nistoreanu P, Pădurean A. M., Nica A. M., and Tănase M. O., 2018, Gastronomy and Tourism, in "New Trends in Sustainable Business and Consumption", BASIQ Conference Proceedings 2018, Heidelberg, Germany

Nistoreanu P. and Tănase M. - O. and Gheorghe G., 2019, PGI and PDO logos and products in the Romanian market. An exploratory study, in "New Trends in Sustainable Business and Consumption", BASIQ Conference Proceedings 2019, Bari, Italy

Richards, G, 2002, Gastronomy: An Essential Ingredient to Tourism production and Consumption, Routledge, in Hjalager, A.M. and Richards, G., Tourism and Gastronomy, pp. 3-20, London

Smith L.J. S. and Xiao H., 2008, Culinary Tourism Supply Chains: A Preliminary Examination, Journal of Travel Research 46(3): 289-29 
Știucă N., 2013, Alimentația tradițională, article published as part of the project "Un polonic de rețete tradiționale. Gastroetnica, gastronomie tradițională în comunitățile multietnice din Dobrogea" - 2013, [online] https:/gastronomietraditionala.ro/alimentatia-in-dobrogea

World Food Travel (2021), What is food Tourism, https://worldfoodtravel.org/what-is-food-tourism/

World Tourism Organization (UNWTO) (2012), Global Report on Food Tourism, 2012, World Tourism Organization (UNWTO), Madrid, Spain, [online] https://www.e-unwto.org/doi/book/10.18111/ 9789284414819. 